https:// doi.org/10.15407/mineraljournal.40.01.003

УДК 55.092

\title{
B.I. Павлишин
}

Інститут геохімії, мінералогії та рудоутворення

ім. М.П. Семененка НАН України

03142, м. Київ-142, Україна, пр-т Акад. Палладіна, 34

E-mail: V.I.Pavlyshyn@gmail.com

\section{УКРАЇНСЬКИЙ ГЕОЛОГІЧНИЙ КОМІТЕТ І ЙОГО КЛЮЧОВІ ПОСТАТІ (до 100-річчя Геологічної служби України)}

Викладено історію зародження, становлення і розвитку Геологічної служби України - Українського геологічного комітету, починаючи з 1917 р. Розглянуто вагомий внесок українських вчених - В.І. Лучицького, Б.Л. Лічкова, В.В. Різниченка та В.М. Чирвінського - у розвиток науки, прикладної геології та Українського геологічного комітету.

Ключові слова: Український геологічний комітет, Геологічна служба України, В.І. Лучицький, Б.Л. Лічков, В.В. Різниченко, В.М. Чирвінський.

До створення Українського геологічного комітету (УГК) геолого-мінералогічні дослідження на сучасній території України здійснювали здебільшого кафедри мінералогії (мінералогії й геогнозії) Харківського, Київського, Новоросійського (нині Одеського), Львівського університетів, Катеринославського вищого гірничого училища (нині Національний гірничий університет України, м. Дніпро), а також академічні установи, університети та природознавчі товариства Австро-Угорщини, Польщі та Рociï [12, 7, 13, 9, 1, 2].

Наші великі попередники, засновники та майбутні активні працівники УГК та Української Академії наук (УАН) - В.І. Вернадський, В.І. Лучицький, В.В. Різниченко, В.М. Чирвінський, Б.Л. Лічков, М.І. Безбородько, П.А. Тутковський та ін. - прекрасно розуміли наукову та практичну доцільність всебічного вивчення перспективних, але на той час мало досліджених мінеральних комплексів України (наприклад, перелік праць, які в тій чи іншій мірі стосувалися мінералогії України до 1917 р. [8], ледь перевищував 60 назв). Водночас вони усвідомлювали, що силами однієї університет-

(с) В.І. ПАВЛИШИН, 2018 ської науки, скромно представленої в Україні на початку XX ст., неможливо вирішити цю складну проблему, особливо коли вона стосується Українського щита (УЩ) [17]. Украй необхідними були нові ефективні форми організації науково-виробничого процесу, який пришвидшили Перша світова війна та революційні події 1917 р.

Питання про територіальне розміщення наукових і виробничих геологічних установ і організацій у величезній Російській імперії виникло задовго до Жовтневого перевороту. Згодом Б.Л. Лічков у друкованому органі УГК "Вісник Українського геологічного комітету" (1919, вип. 1) написав: "уряд старої Росії до смішного боявся усякого сепаратизму: не тільки політичного, але ж⿻ $і$ культурного... Тим часом місиеві осередки наукової праці були необхідні, $i$ наукові працівники на місиях знали це найкраще. Зокрема, численні наукові діячі в межах геологічного досліду території Росії добре розуміли, що одного геологічного осередку для держави замало, що потрібне утворення нових автономних осередків при умовах координації їх праці з працями старого осередку" (цит. за: B.I. Онопрієнко "Володимир Іванович Лучицький", 1991). 
Мова йде передусім про потужний, створений у Петербурзі 1882 р. Геологічний комітет, покликаний скласти загальногеологічну карту Росії й здійснювати детальні роботи в гірничо-промислових районах. Вважається, що ця структура Росії була зразковою науково-виробничою установою, яка зуміла за короткий термін організувати планомірні систематичні дослідження більшості іiі території. До цих робіт як позаштатні працівники (штатних працівників було дуже мало) були залучені фактично всі геологи Росії. У Києві за завданням Геологічного комітету працювали К.М. Феофілактов, В.Ю. Тарасенко, В.І. Лучицький та ін. Проте з часом стало зрозуміло, що впоратися з величезним обсягом завдань геологічного вивчення території Росії лише Геологічному комітету не по силах. Яскравий приклад - Донецький кам'яновугільний басейн. Ні оптимальна організація робіт, ні залучення закордонних фахівців кардинально не вирішували складні проблеми вивчення й ефективного освоєння Донбасу [14]. Тому народилася ідея створення відділень Комітету в різних регіонах Росії, як у самому Комітеті, так і на місцях. Цю ідею було втілено в життя 1 лютого 1918 р. у формі регіональної структури загальногеологічного Геологічного комітету - Українського геологічного комітету, чому передували описані нижче продуктивні організаційні заходи $[15,3$, $10,11,13,16]$.

Оскільки геологи були зосереджені в Київському університеті Св. Володимира, то саме в його надрах народився, оформився і професійно зміцнів УГК. Перші роки діяльності він провів у приміщеннях університету, складався 3 його працівників і випускників, використовував університетську бібліотеку, матеріальнотехнічну та лабораторну базу. Ключову роль у первісних заходах на шляху створення УГК відіграли дві особи - яскравий представник другого покоління феофілактовської школи професор B.I. Лучицький й приват-доцент, майбутній професор Б.Л. Лічков (представник андрусівської школи).

Тривала Перша світова війна. На допомогу фронту в Україні прийшли геологи, об’єднавшись у гідрогеологічній організації "ГидроЮ3" (Гидрогеологическое отделение Управления гидротехнических работ армий Юго-Западного фронта), а також у Відділі сировини Київського комітету військово-технічної допомоги, який став неофіційним філіалом
Петроградської комісії сировини, очолюваної O.Є. Ферсманом.

Відділ сировини, за ініціативою В.І. Лучицького, було створено у березні 1917 р. Сприяв цьому процесу O.Є. Ферсман, який на початку 1917 р. прибув до Києва, щоб проконсультувати київських геологів щодо завдання i принципів діяльності керованої ним Комісії. За даними В.I. Онопрієнка [15], історичні розвідки якого широко використані в цій статті, на першому засіданні Відділу сировини Комітету військово-технічної допомоги, яке відбулося 29 березня 1917 р. в Києві, були присутні 19 геологів. В.I. Лучицький виступив 3 програмною доповіддю. Основними завданнями Відділу, на його думку, повинні бути такі: 1) вивчення гірничо-хімічних багатств на території Південно-Західного фронту та в дотичній смузі; 2) створення бюро для збирання інформації про корисні копалини; 3) дослідження будівельних матеріалів; 4) складання картографічних матеріалів і підготовка брошур; 5) педагогічна діяльність у галузі військової геології.

На загал "ГидроЮЗ" і Відділ сировини виконали надзвичайно великий обсяг розмаїтої, здебільшого геологічної роботи. Наприклад, Відділ сировини за власною ініціативою став до складання двоверстої військово-геологічної карти прифронтової смуги Південно-Західного фронту.

3 настанням миру ці організації було розформовано й на їхній базі утворено цивільного штибу Крайову геологічну раду, яку очолив B.I. Лучицький. Він вважав: оскільки основним напрямом робіт Відділу сировини були геологічні дослідження, то логічно зберегти та розвинути саме цей напрям, надавши йому статус постійної геологічної установи - Українського геологічного комітету, який не конкуруватиме з Геологічним комітетом у Петрограді [15]. Київські геологи, всебічно проаналізувавши пропозицію В.І. Лучицького, вирішили просити його, а також В.М. Чирвінського і Б.Л. Лічкова підготувати проект нової науковопрактичної організації в Києві, зокрема, скласти пояснювальну записку до нього, передбачити штатні одиниці та план роботи на найближчий час.

B.I. Лучицький підготував записку "До питання про створення Украӥнського геологічного комітету", в якій обгрунтував наукову та практичну доцільність створення цієї установи, передусім для геологічного вивчення території 
України, навів проект статуту Комітету. В його основу був покладений статут Геологічного комітету, але з однією принциповою новацією. На думку В.І. Лучицького, УГК, на відміну від Геологічного комітету в Петербурзі, повинен був стати міжвідомчою установою, оскільки геологічні знання необхідні не лише для розвитку промисловості, а й для будівництва, транспорту, військових потреб і навіть медицини. На жаль, ця принципова позиція статуту УГК не могла бути оформлена організаційно в ті роки, але залишилась в його статуті. І УГК практично керувався нею, обслуговуючи геологічні потреби різних державних органів та відомств. Окрім того, в статуті УГК було сформульовано архіважливе положення про те, що Комітет координуватиме та об'єднуватиме всі геологічні роботи, виконувані на території УКраїни. Далі розпочато організаційні кроки перемовини В.I. Лучицького з Міністерством торгу та промисловості, які завершилися високою постановою: статут і штати УГК затверджені урядом 1 лютого 1918 р.

Цією датою започатковано офіційну історію Геологічної служби України у формі УГК. Перший склад комітету обрано на засіданні колишнього Відділу сировини, фактично він об’єднав усіх київських геологів. Міністерство затвердило з 1 лютого 1918 р. директором Комітету В.І. Лучицького, геологами - Г.С. Бурєніна, Б.Л. Лічкова, В.В. Мокринського, В.В. Різниченка, кандидатом у геологи О.В. Красовського. Водночас Г.С. Бурєнін і В.В. Різниченко були прикомандировані до Гідрогеологічного відділу Міністерства земельних справ та визнані позаштатними геологами Комітету. Влітку цього ж року склад Комітету був розширений. До нього ввійшли I.I. Гінзбург, М.І. Безбородько, K.І. Тимофеєв (вихованець Університету Св. Володимира), В.М. Чирвінський, Ф.П. Швець і М.М. Архангельська (вихованка Вищих жіночих курсів). 21 вересня 1918 р. запрацювала Вчена рада УГК (нині б ми сказали Колегія), до якої увійшли, окрім директора, штатних і позаштатних геологів, представники вишів УКраїни: професори П.Я. Армашевський, В.В. Дуб'янський (Університет Св. Володимира), М.Й. Лебедєв і Л.Л. Іванов (Катеринославський гірничий інститут), В.Д. Ласкарьов (Новоросійський університет), Д.М. Соболєв (Харківський університет), С.П. Попов (Новоолександрівський сільськогосподарський інститут). Після заснування УАН до Ради УГК увійшов В.І. Вернадський, який ще на стадії підготовчої роботи зі створення УАН стверджував, що з метою запобігання паралелізму в роботі та марної трати сил і грошей доцільно об'єднати всі геологічні дослідження в єдиному Українському геологічному комітеті, зробивши його міжвідомчим і зв'язавши його 3 Академією наук. Геологи УГК, зокрема, В.I. Лучицький і Б.Л. Лічков, виступили з ініціативою встановлення тісних контактів між УГК і Академією наук. Була навіть висловлена ідея про УГК як один із підрозділів фізико-математичного відділу УАН. На жаль, через об'єктивні причини, цього не сталося. Проте засновані у 1918 р. дві доленосні установи - УГК і УАН пройшли складний шлях взаємостосунків, які вельми позитивно позначилися на розвитку науки, культури та економіки України ще й тому, що в обох структурах працювали одні й ті ж видатні вчені.

У буремні дні 1919 р. В.І. Вернадський заснував і очолив чергову Комісію з вивчення природних багатств України [6], на кшталт Петроградської комісії з вивчення природних багатств і продуктивних сил Росії, в якій об'єднав учених і практиків. До їі складу (всього 30 осіб) увійшли представники УГК - I.I. Гінзбург, В.М. Чирвінський, Б.Л. Лічков, В.І. Лучицький, П.А. Тутковський. 3 цією Комісією була тісно пов'язана Секція підземних багатств України, очолювана професором В.І. Лучицьким, яка входила до складу Українського наукового товариства. Членом цієї секції був також В.І. Вернадський. Комісія і Секція розгорнули роботу широким фронтом - під керівництвом В.І. Лучицького розпочато вивчення корисних копалин України, в тому числі донецького вугілля; запрацював відділ торфу, гідротехнічна секція (В.I. Лучицький); засновано серію "Матеріали по геології України", в портфелі якої було 200 друкованих аркушів, готових до опублікування. Шляхетну мету Комісії - вивчити природні багатства України та напрацювати методи найраціональнішого їх використання - втілюють у життя донині, але останнім часом дуже невдало.

Наприкінці 1919 р. Комісію з вивчення природних багатств України очолив П.А. Тутковський, а секретарем став В.В. Різниченко. Чимало добрих справ Комісії стали спільним доробком УГК і УАН і врешті-решт іiі перетворено на Раду виробничих сил Української РCP. 


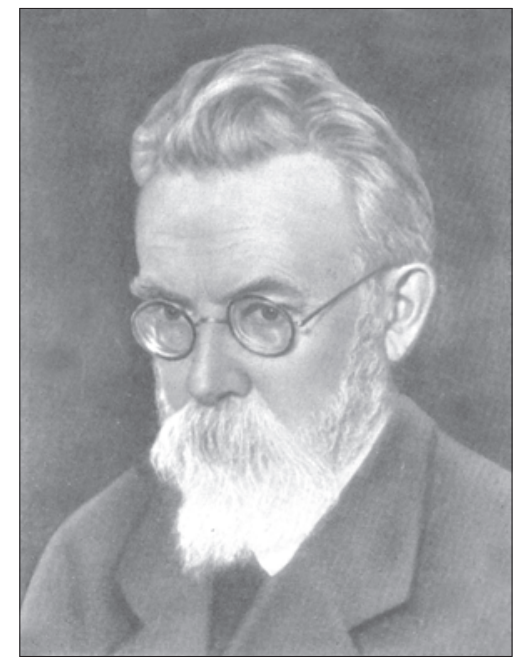

Володимир Іванович ВЕРНАДСЬКИЙ

Volodymyr I. VERNADSKY

Не забував В.І. Вернадський про УАН і УГК, знаходячись поза межами України. В.Л. Лічкову 10 грудня 1922 р. він писав: "Я часто думаю о Вас и о всех в Киеве, об Академии, Геологическом комитете, Украине... Послал свои работы, еще начатые в Киеве, не знаю дошли ли" (Переписка В.И. Вернадского с Б.Л. Личковым, 1979, т. 1, с. 27).

Повертаємося до УГК. 1918 р. відбулося 25 засідань УГК, п'ять засідань Комісії з корисних копалин і три - Комісії з будівельних матеріалів, на яких обговорено широке коло питань - проект статуту Комітету, план його робіт, кошторис, обрання членів та співробітників Комітету, ставлення до УАН, координація діяльності УГК і Гідрогеологічного відділу Міністерства земельних справ, відповіді на запити Гірничого департаменту та інших відомств, план польових робіт на літо 1918 р., інструкції до складання геологічної карти корисних копалин, кошторис на 1919 р., інші документи та матеріали. На жаль, у 1918 р. діяльність Комітету була здебільшого лабораторно-кабінетною: складні політичні та воєнні події в УКраїні перешкодили польовим дослідженням. Тому вирішили зібрати та систематизувати всі матеріали з геології, напрацьовані до того часу. Для цього було складено карту дослідженості території України, яка наочно показала, що 60-верста геологічна карта Геологічного комітету вже не задовольняла потреб регіонального вивчення України.

Водночас геологи Комітету почали складати карту корисних копалин України в 10-верстому масштабі, яка за ступенем детальності повинна була істотно відрізнятися від подібної геологічної. Комітет розпочав складання і 10верстої карти будівельних матеріалів України. Ідея В.І. Лучицького полягала в тому, щоб ці три карти доповнювали одна одну та разом створили цілісний образ стану геологічної дослідженості території України. Складання карт вимагало копіткої роботи з літературними джерелами - друкованими і рукописними, перевірки та коригування літературних даних на місцях. Ця найнеобхідніша праця мала стати фундаментом для покажчика літератури з корисних копалин та відповідних довідників як необхідних додатків до карт. Для розширення бази своїх даних УГК зібрав відомості про адреси рудників, кар'єрів, заводів, фабрик, що оброблювали мінеральну сировину, і надіслав їм спеціальні анкети. Було одержано 60 відповідей від 38 установ, фабрик та осіб стосовно 116 кар'єрів корисних копалин та будматеріалів, про 60 родовищ цілющих джерел, озер та грязей, а також геологічних розрізів багатьох свердловин уздовж ліній залізниць. Для довідників з корисних копалин та будматеріалів, а також для загального уявлення про геохімію надр України Комітет зібрав тисячу розмаїтих результатів аналізів корисних копалин, гірських порід, мінералів, грунтів тощо.

Для виконання лабораторних досліджень будматеріалів України було організовано спеціальну комісію, до складу якої увійшли В.I. Лучицький, В.М. Чирвінський, М.I. Безбородько, K.I. Тимофєєв, М.М. Архангельська (остання займалася обробкою зразків будматеріалів із колекцій Київського університету та Політехнічного інституту). Вже у 1918 р. УГК дав багато відповідей на запити різних відомств щодо місцезнаходжень кам'яного та бурого вугілля, кременів, глин, графіту.

1919 р. був надзвичайно тяжким для УГК, УАН та Університету, в зв'язку з подіями Громадянської війни. Неможливими стали не тільки польові дослідження, а й усілякі роботи взагалі, оскільки фактично Комітет не одержував жодних коштів для своєї діяльності. Лише наприкінці 1920 р. стан Комітету став поліпшуватися. У 1921 р. був затверджений кошторис УГК - вперше в такому обсязі, що з'явилася можливість провести літні польові роботи.

Але цих асигнувань все-таки було недостатньо для розгортання повнокровних польових робіт, і тому УГК уклав договір з Управлінням 
гірничопромислових розвідок Південно-Західного району ("Югзаппромразведка") і на його кошти відправив у поле 10 партій. Зокрема, В.М. Чирвінський досліджував буровугільні родовища Херсонщини, М.I. Безбородько геологію родовищ будматеріалів на Поділлі, а Р.Р. Виржиковський - Подільський фосфоритовий район (розробив план відродження фосфоритової промисловості), В.В. Різниченко жорнові пісковики; В.І. Лучицький, Р.М. Палій, О.В. Красовський вели геологічну зйомку тощо. Підсумки робіт партій в 1921 р. були опубліковані в перших виданнях "Праць" Комітету. У цьому ж році організовано Катеринославський філіал УГК, який, на жаль, функціонував недовго.

1922 року геологічна служба в Україні була кардинально реорганізована. 1 жовтня 1922 р., у зв'язку з затвердженням нового положення про Геологічний комітет у Петрограді, УГК був перетворений на автономну філію останнього, якій доручалося продовжувати дослідження на території республіки. Водночас було винесено рішення про приєднання до Українського відділення Геологічного комітету (УВГК) "Югзаппромразведки", або Української філії Центрального управління промислових розвідок. 3 приєднанням УГК до Геологічного комітету вперше визначено постійний штат УВГК 14 одиниць, а з приєднанням "Югзаппромразведки" - 23 одиниці. До складу Відділення в 1923 р. увійшли В.І. Лучицький (голова та завідувач Бюро обліку), О.В. Красовський, В.М. Чирвінський та О.Є. Зеленко, геологирозвідники В.В. Мокринський та С.Г. Коклик, позаштатні геологи-співробітники В.С. Левитський, М.В. Фремд, Р.М. Палій. До Наукової ради відділення увійшли акад. АН УРСР П.А. Тутковський і проф. В.В. Дуб'янський. Павло Аполлонович, переобтяжений академічною роботою, поступово відходив від УГК і в 1926 р. створив Інститут геологічних наук (ІГН) НАН України (сучасна назва) [11].

1923 р. Відділ регіональної геології організував польові роботи, в яких брали участь й університетські геологи. Так, Б.Л. Лічков проводив дослідження в північно-східній частині 32-го аркуша 10-верстої геологічної карти і займався картуванням у Звенигородському повіті; Р.Р. Виржиковський продовжував вивчати фосфоритовий район в Могильовському повіті, P.М. Палій - в Ізюмському. Протягом камерального періоду В.І. Лучицький обробив ма- теріали з гідрогеології України та петрографії Українського щита, Б.Л. Лічков - 3 тектоніки України та стратиграфії Мангишлака, а В.В. Дуб’янський - з петрографії та мінералогії пегматитів Волині тощо.

У 1923 р. при УВГК були створені комісії: каолінова (В.І. Лучицький, С.Г. Коклик, Б.Л. Лічков, Б.С. Лисін, Ю.І. Фрейвальд, М.В. Фремд, В.М. Чирвінський), з вивчення кір вивітрювання (Б.Л. Лічков, М.І. Ожегова, В.М. Чирвінський), буровугільна (В.І. Лучицький, П.І. Василенко, С.Г. Коклик, Б.Л. Лічков, В.М. Чирвінський), гідрогеологічна (В.І. Лучицький, Г.С. Бурєнін, Є.Л. Лічкова, Б.Л. Лічков, В.В. Різниченко).

УВГК стало однією з перших установ в УКраїні, яка напрацювала п'ятирічний план розвитку регіонально-геологічних досліджень в 1924-1929 рр. У ньому ключовою була ідея про перехід в Україні до детальніших зйомок, ніж десятиверстого масштабу. Неможливо не визнати стратегічне значення першого п’ятирічного плану, розробленого УВГК та ухваленого на засіданні Наукової ради 12 травня 1923 р. Найближчими завданнями геологи України вважали вивчення родовищ фосфоритів та каолінів, які мали виняткове значення для відродження в Україні фосфоритової, фарфорової та паперової промисловості. Саме тому під керівництвом В.І. Лучицького здійснювалося детальне дослідження Подільського фосфоритового району і каолінових родовищ (В.В. Мокринський, О.Є. Зеленко, С.І. Баженов та ін.). Без будь-якої допомоги з боку інших установ, УВГК відновило роботу двох зруйнованих каолінових заводів - Лозовиковського та Райковського і розвідало кілька родовищ каоліну: В.В. Мокринський - Лозовиковське, О.Е. Зеленко - Новоселицьке, Паланкінське та Курделевське, В.С. Левитський - родовище Вертиєва Балка, М.В. Фремд - Райновське, C.I. Баженов - Турбівське, Ю.В. Фрейвальд - родовища Катеринославського району.

Новим у діяльності УВГК в 1923-1924 рр. стало складання карт різних геологічних систем, систематизація бібліографії геологічної літератури 1918-1923 рр., складання оглядів гірничої промисловості України. Триверсту зйомку виконували: В.М. Чирвінський - у Звенигородському районі, Р.Р. Виржиковський - у Придністерському, Р.М. Палій - в Північно-Ушицькому. У зв'язку з великими зсувами в Києві була здійснена детальна гео- 
логічна зйомка міста, підсумком якої стала геологічна карта Києва 3 докладним описом та інженерно-геологічною характеристикою. Ця робота поклала початок планомірній боротьбі 3 київськими зсувами. Видано збірник з корисних копалин України, в якому були статті: "Уголь Украины" (Б.Л. Лічков), "Графиты УКраины" (В.М. Чирвінський), "Каолиновые месторождения Подолья" (О.С. Зеленко), "Железная руда Волыни" (С.Г. Коклик), "Никопольское марганцевое месторождение" (М.В. Черногорова), "Ртуть Украины" (М.І. Ожегова).

У 1924 р. Держплан виділив кошти на пошукові роботи з метою покращення водопостачання Юзівки. Проведення робіт було доручено Донецькому меліоративному бюро, а організація гідрогеологічної розвідки - В.І. Лучицькому. Восени 1924 р. він сформував гідрогеологічну партію, завданням якої було визначення ресурсів водопостачання питною водою Юзівки та інших населених пунктів Донбасу. Роботи охопили верхню течію річок Кривий Торець, Кальміус, лівобережжя Вовчої загальною площею розвідки - 1359 кв. верст. Проведено гідрогеологічне районування, складені триверста геологічна та гідрогеологічна карти, а також зібрані відомості з петрографії, палеонтології, хімічного складу вод району, що дало змогу зробити повний гідрогеологічний опис і гідрогеологічні карти одноверстого масштабу та розробити практичні рекомендації. Під керівництвом В.І. Лучицького та Р.М. Палія велись також роботи, скеровані на поліпшення водопостачання Артемівська.

На межі 1924-1925 рр. союзні відомства різко зменшили асигнування, що спричинило скорочення штатів УВГК до чотирьох штатних одиниць. Тим самим під загрозу було поставлено здійснення п'ятирічного плану. Але завдяки підтримці українського уряду та ВРНГ УРСР у Києві, було розроблено та затверджено ВРНГ УРСР "Положення про Український геологічний комітет" як самостійну організацію з постійним штатом у 20 співробітників. У квітні 1925 р. Раднарком УРСР виділив з резервного фонду на утримання персоналу та літні польові роботи 25 тис. крб. Така підтримка відновила нормальну діяльність геологічної установи.

У 1925 р. на польові роботи виїхало 20 партій: сім із них фінансувалися з бюджету СРСР, сім - з бюджету УРСР, шість - зі спецкоштів. Для з'ясування питань регіональної геології виконували триверсту зйомку (партії Р.Р. Виржиковського, В.М. Чирвінського, Г.С. Бурєніна). Окрім того, партії В.I. Лучицького та Б.Л. Лічкова займалися 10-верстою зйомкою аркушів 31 та 32, тривала детальна зйомка Канівських дислокацій. Завдяки допомозі республіканських керівних органів було намічено нові райони для триверстої зйомки - УшомирОвруцький (Л.А. Крижановський та М.І. Ожегова) та Маріуполь-Волноваський (В.І. Лучицький та А.А. Цитович). На союзні кошти працювала Побузька партія В.В. Мокринського з пошуків каолінів, графітів та залізних руд; на республіканські - чотири партії: дві (Р.М. Палія та Р.Р. Виржиковського) - на фосфорити Поділля, партія О.Є. Зеленка - на ізюмські фосфорити та партія Й.І. Танатара з вивчення газоносності Приазов'я.

У 1926-1927 рр. становище Укргеолкому зміцнилося, розширилась наукова тематика. Завдяки розвитку зв'язків із урядом УРСР та центральним Геологічним комітетом значно зросли його штати та фінансові можливості. У 1926 р. Комітету пощастило взяти в оренду будинок по вул. К. Лібкнехта, 34 і нарешті переїхати з приміщень Університету. Велике значення для зміцнення авторитету Комітету мала організація та проведення у 1926-1927 pp. у Києві Другого Всесоюзного геологічного з'їзду, який став важливим етапом у розвитку геологічної науки в Україні. Головою з’їзду був обраний В.I. Вернадський. Активну участь у його роботі брали В.І. Лучицький, Б.Л. Лічков, М.І. Безбородько, В.М. Чирвінський, П.А. Тутковський.

Геологи Комітету влітку 1926 р., відповідно до п’ятирічного плану, здійснили потужні польові роботи. Бюро розвідок, за дорученням різних установ та за їхні кошти, виконало розвідувальне буріння фосфоритів Поділля для суперфосфатного комбінату, каолінів біля станції Долинської - для Центрпапіртресту, буріння з метою одержання артезіанських вод для будинку відпочинку ВУЦВК. Були розгорнуті роботи з гірничо-економічної зйомки Поділля та Донбасу.

У 1926-1927 рр. відбулися також серйозні зміни в політиці Геологічного комітету в Ленінграді шодо своїх відділень, розширено організаційну, наукову та частково фінансову допомогу їм. Були створені секції: геологічної зйомки, гідрогеологічна, петрографічна, палеонтологічна; комісія з вивчення четвертинних 
відкладів, засновані шліфувальна майстерня, хімічна лабораторія. Зміцнились зв'язки з гірничим відділом ВРНГ УРСР, трестами, господарськими органами республіки, Всеукраїнською Академією наук тощо.

Таким чином, 1927 р. можна вважати роком остаточного становлення центрального органу і системи Геологічної служби України. Окрім вирішення власне виробничих завдань, вони досягли і значних наукових результатів, які 12 березня 1928 р. у день святкування десятиріччя Укргеолкому відзначив В.М. Чирвінський у доповіді "Про наукові досягнення Українського відділення Геологічного комітету в галузі регіональної геології за 10 років його існування", а також М.I. Безбородько у доповіді "Українська кристалічна смуга і корисні копалини України". Серед найважливіших наукових досягнень, зокрема, названо відкриття Р.Р. Виржиковським і Р.М. Палієм дислокованих товщ силурійських відкладів (до цього вважали, що силур залягає тут непорушено), відкриття на Поділлі Р.Р. Виржиковським палеогенових осадочних порід (район с. Хощевате), проведення В.І. Лучицьким та Д.М. Соболєвим стратиграфічного розчленування докембрію Українського щита, петрографічний опис кристалічних порід Приазов'я.

Винятково актуальними виявилися гідрогеологічні дослідження Поділля, Київщини, Чернігівщини, Полтавщини та Донбасу, виконані під керівництвом В.І. Лучицького, які завершено підготовкою якісних гідрогеологічних карт із зображенням найголовніших водоносних горизонтів.

Отже, протягом 1918-1928 рр. УГК закладено основи систематичного вивчення найголовніших корисних копалин, складено геологічну, гідрогеологічну карту й карти корисних копалин України, отримано нові дані зі стратиграфії докембрію УЩ, палеозою Поділля, мезо-кайнозою ДДЗ, виявлено новітні дислокації в околицях Канева та Придністер'я, розширено мінерально-сировинну базу буровугільних родовищ, каолінів, фосфоритів, манганових і залізних руд, графіту, будівельних матеріалів. Певну роль у діяльності УГК відіграла його Вчена рада і друкований орган Вісник Українського відділення Геологічного комітету, інша друкована продукція, в тому числі путівники геологічних екскурсій тощо.

Укргеолком очолювали впродовж його десятилітньої діяльності видатні вчені - В.І. Лу-

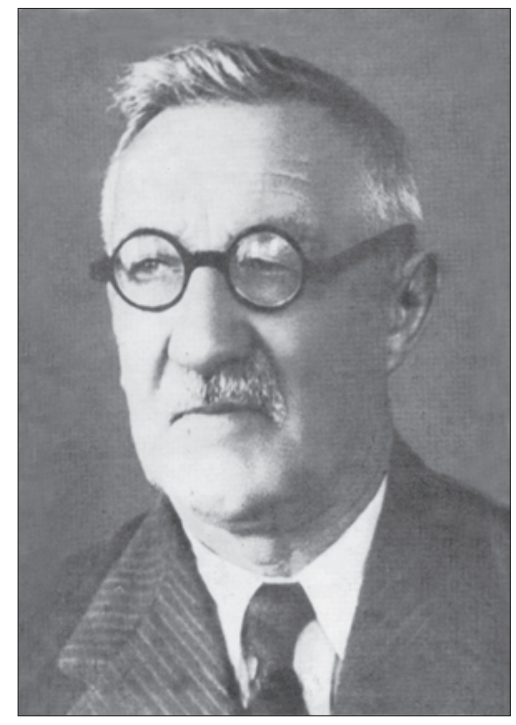

Володимир Іванович лУЧИЦЬКИЙ

Volodymyr I. LUCHYTSKY

чицький (1918-1924), Б.Л. Лічков (19241926), В.В. Різниченко (1927-1928).

Володимир Іванович Лучищький (1877-1949) видатний вчений у галузі петрографії інтрузивних, вулканогенних, метаморфічних порід i геології корисних копалин УЩ та інших регіонів колишнього СРСР. Народився 21 квітня 1877 р. у Києві, навчався в Третій київській чоловічій гімназії (1887-1895) і на природничому відділенні фізико-математичного факультету Університету Св. Володимира, який з золотою медаллю закінчив у 1899 р. Першу наукову працю "О микроскопическом строении некоторых третичных песчаников Южной России" опублікував 1901 р. На фізико-математичному факультеті Київського університету захистив докторську дисертацію "Рапакиви Киевской губернии и породы его сопровождающие" (1912). У вченому ступені доктора наук затверджений Вищою атестаційною комісією СРСР без захисту дисертації 1934 p.

B.I. Лучицький - автор оригінального підручника "Петрография" (витримав шість видань: перше - 1910, шосте - 1919 р.). Викладав різні дисципліни у вишах Києва, Варшави, Москви та Криму. 1918 р. як директор очолив УГК, а в 1924 р. вимушено покинув Київ і переїхав до Москви, де працював у різних інститутах. Виїхавши з України, вчений не поривав з нею зв'язок. Усіма способами організовував польові геологічні дослідження на території України, фінансову підтримку УГК, впливав 


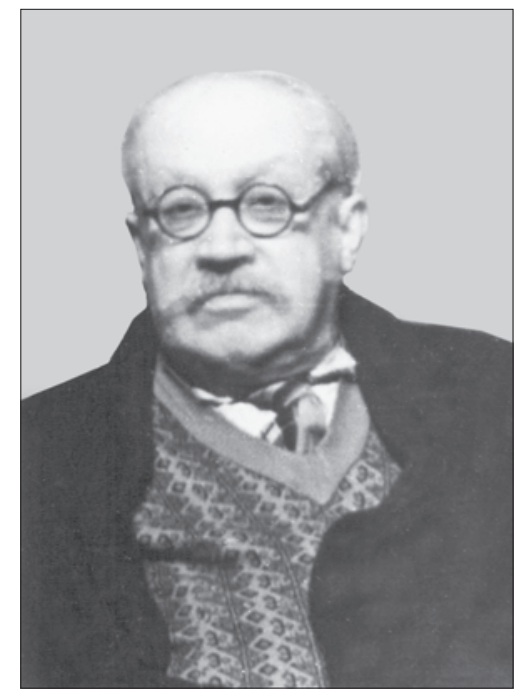

Борис Леонідович ЛІЧКОВ

Borys L. LICHKOV

на розвиток продуктивної взаємодії УГК і УАН. 1944 р. В.І. Лучицький знову приїхав в Україну і був зарахований завідувачем відділу петрографії ІГН АН УРСР. Через рік його обрано академіком і запрошено на посаду професора кафедри мінералогії і петрографії Київського університету. У 1946-1949 pp. В.І. Лучицький - директор ІГН АН УРСР. На цій посаді він перебував до самої смерті, яка настала 20 жовтня.

Наукові інтереси В.І. Лучицького надзвичайно широкі - кристалографія і кристалохімія, мінералогія, петрографія, питання регіональної геології, корисні копалини, гідрогеологія і гідрогеохімія, літологія і кори вивітрювання, радіоактивні мінерали, геологічна зйомка і пошуковорозвідкова справа, серед яких чи не на перше місце вийшли проблеми докембрію Українського кристалічного масиву, віддзеркалені в низці капітальних публікацій: "К вопросу о происхождении гранитов юга России" (1910), "Материалы по петрографии юга России: рапакиви Киевской губернии и породы, его сопровождающие" (ч. 1, 1911; ч. 2, 1912), "Полезные ископаемые Украины" (1923, 1933), "Вопросы стратиграфии и тектоники Украинской кристаллической полосы" (1930), "Петрография Украины" (ч. 1, 1934), "Общий обзор докембрия Европейской части СССР" (1939), "Стратиграфия докембрия Украинского массива" (1939), "Український кристалічний масив" (1947, у співавторстві).

Золота сторінка життя і діяльності В.І. Лучицького - підготовча робота (участь к роботі
"ГідроЮЗу", заснування Відділу сировини Комітету військово-технічної допомоги) та організація на їхній базі Геологічної служби України у формі УГК. В.М. Чирвінський свою доповідь (див. вище) з нагоди 10-річчя УГК завершив такими словами: "... я вважаю, не можна не визнати, що Українське відділення Геологічного комітету проробило значну наукову роботу в справі вивчення геології України, що треба великою мірою пояснити відданістю і любов'ю до своєї справи геологів і співробітників УВГК та енергією першого їі організатора і директора В.І. Лучицького".

Борис Леонідович Лічков * (1886-1966) - відомий гідрогеолог, стратиграф і палеонтолог України, активний діяч у справах організації УГК і УАН. Ним пишався В.І. Вернадський.

Лічкови перебували у родинних зв'язках 3 Чирвінськими - П.М. і В.М. Чирвінські та Б.Л. Лічков були двоюрідними братами, що вплинуло на професійний вибір останнього.

Борис Лічков закінчив Києво-Печерську гімназію і природниче відділення фізико-математичного факультету Університету Св. Володимира (1918) ** [16]. У студентські роки найбільший вплив на формування світогляду молодого вченого мав університетський професор Микола Іванович Андрусов (18611924). Фактично він належав до андрусівської геологічної школи.

Зі щоденникових записів В.І. Вернадського від 4 червня 1918 р. дізнаємося, що "накануне выяснился план организации Комиссий и наметились секретари". У Комісію зі створення УАН Вченим секретарем призначено В.Л. Модзалевського. У Комісії з вищих навчальних закладів і наукових установ Вченим секретарем став молодий геолог Б.Л. Лічков, з яким у B.I. Вернадського склалися дружні стосунки, що тривали усе його життя (B.I. Вернадський в

* У публікаціях є два україномовні написи прізвища вченого - Лічков і Личков.

** Ймовірно, це помилкова дата закінчення Київського університету. Відомо достеменно, що Борис Лічков у 1917 р. увійшов до складу Відділу сировини, у цьому ж році брав участь, спільно з В.І. Лучицьким і В.М. Чирвінським, у підготовці проекту УГК. Зрозуміло, що це не рівень студента. Окрім того, відомо, що В.I. Лучицький 3 Варшави 11.05.1911 р. відправив листа Б.Л. Лічкову, в якому він запрошує Б.Л. Лічкова посісти посаду асистента на його кафедрі. У листі є питання - "держите ли Вы теперь государственные экзамены" [15]. Найімовірніша дата закінчення Університету - 1911 р. (у 25 років).

ISSN 2519-2396. Mineral. Journ. (Ukraine). 2018. 40, No 1 
1918-1945 рр. надіслав Б.Л. Лічкову 177 листів). Ймовірно, цьому високому призначенню Б.Л. Лічкова передувала характеристика В.І. Лучицького, який вважав його талановитим геологом та організатором наукової думки. Ці якості особливо проявилися під час його роботи в Київському товаристві природознавців, "ГідроЮЗі" й в Комісії сировини, у процесі складання спільно з В.І. Лучицьким і В.М. Чирвінським проекту УГК та пояснювальної записки до нього. Успішно працював Б.Л. Лічков також у Секції підземних багатств (1919) і гідрогеологічній секції (1919) Комісії з вивчення природних багатств України.

В університетському Геологічному кабінеті Борис Леонідович працював штатним лаборантом. 1919 р. був запрошений до викладання на природничому факультеті Київського університету, у 1924-1927 pр. очолював науководослідну кафедру геології Київського інституту народної освіти. Він автор ротаторного підручника "Історична геологія" (1919) для студентів Київського університету [2], що дало змогу йому отримати звання приват-доцента.

Наукові інтереси Б.Л. Лічкова розмаїті - від досліджень у галузі палеонтології й стратиграфії, гідрогеології й гідрогеологічного районування УЩ до питань геотектоніки, геоморфології й історії науки.

1927 р. на запрошення В.I. Вернадського Б.Л. Лічков переїхав з Києва до Ленінграда, де обіймав посаду Вченого секретаря Комісії (потім Ради) з природних виробничих сил (19271934). Водночас працював у Геоморфологічному інституті, завідував відділом підземних вод у Гідрогеологічному інституті й кафедрою гідрогеології в Ленінградському університеті (1930-1934, 1946-1966) [16].

5 липня 1934 р. Б.Л. Лічков був арештований й невдовзі засуджений за абсолютно брехливим звинуваченням. Лише 17 січня 1941 р. "освободился от Волгостроя". Після звільнення працював у різних установах Середньої Азії, в останні роки - професором у Ленінградському університеті.

Можна висловити припущення, що зірковим часом життя і діяльності Б.Л. Лічкова була науково-практична робота, скерована на підготовку, організацію і заснування Українського геологічного комітету, який він очолив як директор у важкі 1924-1926 рр. після від’їзду B.І. Лучицького до Москви. Справді, в ці роки неймовірно посилився диктат центральних

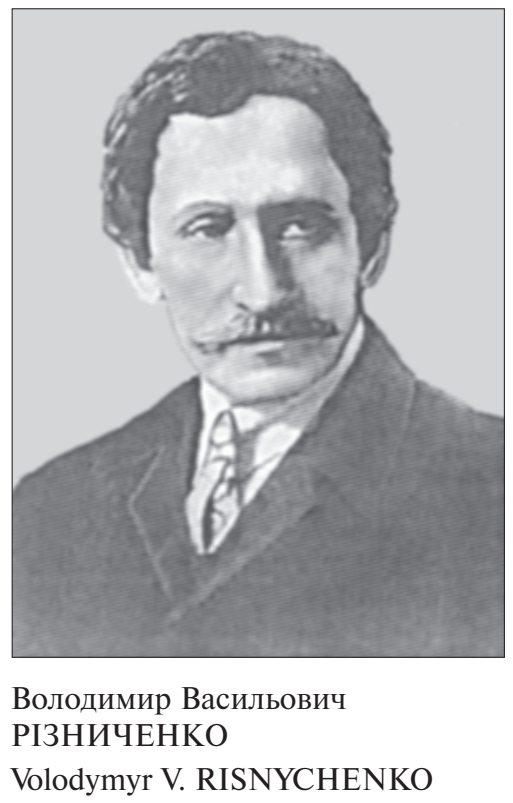

органів, через що штат УВГК скоротився до чотирьох геологів. Виникла загроза зриву геологічних досліджень. Б.Л. Лічков спільно зі своєю командою, в яку заочно входив В.І. Лучицький, домігся затвердження ВРНГ УРСР нового положення про "Український геологічний комітет", в якому передбачено штат із 20 співробітників і відповідне фінансування. Ця реформа остаточно відділила УГК від центрального Геологічного комітету, внаслідок чого було відновлено нормальну діяльність геологічних підрозділів. Згадаємо ще Другий Всесоюзний з'їзд геологів (1926), який продемонстрував великі можливості наукової школи УГК, сформованого В.I. Лучицьким і Б.Л. Лічковим.

Володимир Васильович Різниченко (18701932) - видатний український вчений у галузі четвертинної геології, геоморфології, тектоніки, гляціології, географії [11, 18].

Народився у с. Валентіїв Ніжинського району Чернігівської області, навчався у Ніжинській гімназії (закінчив 1891 р.); Харківський університет закінчив з вільним дипломом (1896). Деякий час жив і працював у Москві та Петербурзі.

В.В. Різниченко досліджував льодовики Алтаю, Тянь-Шаню і Тарбагатаю, антропогенові відклади та тектоніку Середнього Придніпров'я. За фундаментальні дослідження в Середній Азії й на Алтаї був нагороджений Золотою медаллю ім. М.М. Пржевальського. 1912 р. він опублікував фундаментальну працю "О древних и современных ледниках Юго-Западного Алтая". 


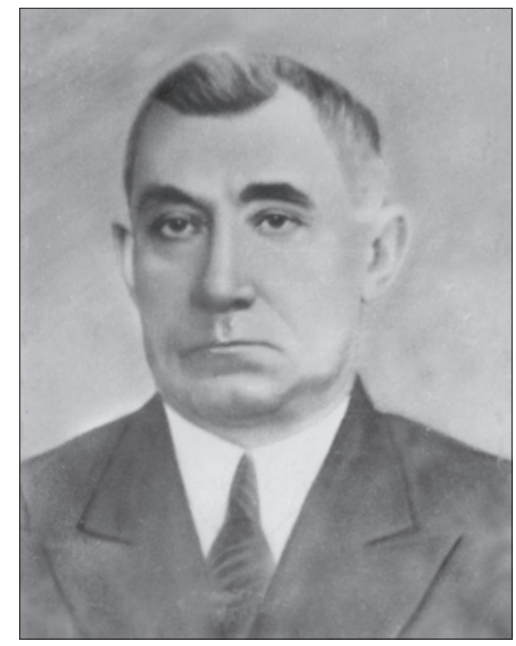

Володимир Миколайович ЧИРВІНСЬКИЙ

Volodymyr M. CHYRVINSKY

Вроджена та безмежна любов до батьківщини фактично визначила другий період його наукової діяльності (1916-1932), пов'язаний з Україною, якій віддав всі свої сили й знання. У кар'єрі В.В. Різниченка важливими були три щаблі - третій директор УГК (1827-1928), обрання в 1929 р. академіком, другий директор ІГН АН УРСР (1930-1932).

3 часу проголошення УНР і організації в 1918 р. УГК В.В. Різниченко працював позаштатним, згодом штатним геологом, був одним із ініціаторів триверстої геологічної зйомки України, в якій безпосередньо брав участь, переважно на лівобережжі Середнього Дніпра.

В.В. Різниченко плідно працював у різних місцинах України, але найбільше в районі Канівських дислокацій у межах Середнього Придніпров'я, яким присвятив чимало праць, у тому числі книгу "По ярах та кручах Канівських гір" (1928). Він організував Комісію з вивчення четвертинних відкладів України та започаткував періодичне видання збірника "Четвертинний період".

В.В. Різниченко вперше порушив питання про організацію заповідника на могилі Т.Г. Шевченка. Він опублікував "Геологічний нарис околиць Шевченківської могили". Все це гармоніювало 3 широким авторитетом вченого, відомого також як громадський діяч, художник-карикатурист, поет і перекладач, член Наукового товариства ім. Т.Г. Шевченка у Львові. Помер В.В. Різниченко передчасно від сухот 1 квітня 1932 р. Похований на Лук'янівському цвинтарі.
Під час роботи В.В. Різниченка директором УГК, Комітет як ніколи зміцнів професійно та структурно. Всі його служби згодом були успішно реорганізовані в Українське районне геологорозвідувальне управління (19291931).

Володимир Миколайович Чирвінський (18831942) - відомий київський мінералог, петрограф, педагог, фактично науковий керівник геологічної зйомки та регіональних досліджень у роки функціонування УГК.

Першу київську гімназію закінчив зі срібною медаллю у 1902 р. Потім навчався на природничому відділенні фізико-математичного факультету Університету Св. Володимира (19021907). По закінченні університету В.М. Чирвінський був залишений стипендіатом для підготовки до професорського звання по кафедрі мінералогії (науковий керівник П.Я. Армашевський).

Приват-доцент Володимир Чирвінський $з$ осені 1914 р. читав курс петрографії, працював здебільшого в університетському Геологічному кабінеті, який нечувано збагатив кам'яними колекціями. 31911 по 1916 р. В.М. Чирвінський викладав геолого-мінералогічні дисципліни в Київському політехнічному інституті (КПI), а в 1916 р. очолив тут кафедру мінералогії й геології і створений ним Геологічний кабінет, які до кінця життя стали його постійним місцем роботи, хоча паралельно працював і в інших установах. Помер В.М. Чирвінський під час Другої світової війни у холоді і голоді на території КПІ [16], похований на Лук'янівському цвинтарі.

Першу наукову працю В.М. Чирвінський опублікував у 1907 р., останні дві - в 1941 р. У цьому проміжку часу наукова тематика досліджень ученого часто й істотно змінювалася, тут стисло висвітлено лише деякі теми та результати. Повнішу інформацію можна почерпнути в книзі В.I. Онопрієнка, М.В. Онопрієнка "Чирвинские" (2008) [16].

Розпочаті ще в студентські роки дослідження фосфоритів, які тоді вважали аморфними речовинами, тріумфально завершилися відкриттям нового мінералу - подоліту. У магістерській дисертації (1916) Володимир Миколайович докладно висвітлив мінералогію й хімію льодовикових відкладів Південно-Західної Росії та встановив напрямки їхнього руху, які згодом виявилися принципово важливими для розробки проблем четвертинної геології. Ори-

ISSN 2519-2396. Mineral. Journ. (Ukraine). 2018. 40, No 1 
гінальною, якщо не сказати сенсаційною, стала ще одна піонерська праця "Химический состав колонны осадочных пород г. Киева" (1917), яку високо оцінив В.І. Вернадський. Значну частину свого життя вчений присвятив буровугільній тематиці, дав прогнозну оцінку мангановим рудам, розширив дослідження фосфоритів України, геологічно описав свердловину, пробурену на території КПІ, досліджував графіти, вулканіти, тераси річок...

У науковій біографії В.М. Чирвінського особливе місце посідає розмаїта робота в УГК, до організації якого він долучився найактивніше спільно зі своїм старшим колегою В.I. Лучицьким і двоюрідним братом Б.Л. Лічковим. Найплідніша його діяльність тут стосувалась геологічного картування території України та регіональних геологічних досліджень, які впродовж тривалого часу він сумлінно й професійно очолював, хоча не цурався й іншої роботи. У зв'язку з хронічним дефіцитом кадрів B.M. Чирвінський часто був одним із головних виконавців цих робіт. Коли стало зрозуміло, що 60-верста геологічна карта Геологічного комітету не задовольняє практичних потреб, було вирішено розпочати складання різного роду карт у 25 і 10-верстому масштабі, а в окремих випадках і детальнішого, наприклад триверстого масштабу.

Не випадково саме В.М. Чирвінському було доручено виступити з генеральною доповіддю "Про наукові досягнення Українського відділення Геологічного комітету в галузі регіональної геології за 10 років його існування" (див. вище) на зборах, присвячених десятилітньому ювілею УГК (1918-1928). У ній він підбив підсумок найголовнішим і вражаючим досягненням УГК, якими закладено фундамент для подальшої співзвучної часу реорганізації УГК і створення на його базі нових геологічних служб. 3 ними В.М. Чирвінський співпрацював до кінця 1930-х рр.

Натепер можемо інституційно диференціювати столітню історію Геологічної служби України, яка нині називається Державною, і складається з понад 20 послідовних етапів розвитку [5], серед яких відмітимо такі:

1. Український геологічний комітет (19181922);
2. Українське відділення Геологічного комітету (1922-1929);

3. Українське районне геологорозвідувальне управління (1929-1931);

4. Український геологорозвідувальний трест (1931);

5. Українське геологічне управління (1941);

6. Головне управління геології та охорони надр (Головгеологія УРСР, 1957);

7. Міністерство геології УРСР (1965);

8. Геологічне виробниче об'єднання (Укргеологія, 1988);

9. Державний комітет України з геології та використання надр (Держкомгеології, 1991);

10. Комітет України з питань геології та використання надр (1999);

11. Департамент геології та використання надр Міністерства екології та природних ресурсів України (2000);

12. Державна геологічна служба - урядовий орган державного управління у складі Мінекоресурсів України (2001);

13. Державна геологічна служба як урядовий орган державного управління у складі Міністерства охорони навколишнього природного середовища України (2005-донині).

Геологічна служба України, незалежно від назви, організовує і втілює в життя програму, зазвичай, планомірного геологічного вивчення надр України з метою забезпечення потреб народного господарства мінерально-сировинними ресурсами.

За даними сучасної Геологічної служби [4], Україна має потужну та розвинену мінеральносировинну базу, чи не найкращу в Європі. Досить сказати, що, наприклад, в 1991 р. Україна забезпечувала 5 \% світового видобутку мінеральної сировини, а за рахунок експорту гірничорудної сировини і виробів з неї отримувала понад 60 \% валютних надходжень. Так було, коли більш-менш гармонізовано взаємодіяв трикутник: геологічна освіта - геологічна наука - геологічна галузь. Нині, здебільшого через економічну кризу, освіта "на ладан дихає", наука ледь-ледь жевріє, а геологічна галузь "випала" з цього трикутника та перетворилася на "нелегальну" стосовно академічних і освітянських вчених організацію. Так буде допоки в Україні пануватиме корупція. 


\section{ЛІТЕРАТУРА}

1. Геологічний факультет Львівського національного університету імені Івана Франка. Вид. друге / П. Білоніжка, О. Матковський, М. Павлунь, Є. Сливко. - Львів : ВЦ Львів. нац. ун-ту, 2010. - 520 с.

2. Геологія в Київському університеті / За ред. В.І. Павлишина. - К. : ВПЦ Київ. ун-т, 2011. - 479 с.

3. Гошовський С.В., Гурський Д.С. Державній геологічній службі України 80 років // Мінеральні ресурси України. - 1998. - № 1. - С. 3-5.

4. Гурський Д.С. Концептуальні засади державної мінерально-сировинної політики щодо використання стратегічно важливих для економіки країни корисних копалин. - Львів : ЗУКЦ, 2008. - 192 с.

5. Державна геологічна служба. - К., 2006. - 19 с.

6. Історія Академії наук України. 1918-1923. Документи і матеріали. - К. : Наук. думка, 1993. - 563 с.

7. История минералогических исследований на Украине. Сб. науч. тр. / Отв. ред. Ю.П. Мельник. - Киев : Наук. думка, 1991. - $160 \mathrm{c}$.

8. Лазаренко E.K. Развитие минералогии в Украинской ССР за 30 лет советской власти // Минерал. сб. - 1948. № 2. - C. 5-24.

9. Ларченков Е.П., Кравчук О.П., Кравчук А.О. Геология в Одесском университете. - Одесса : Фенікс, 2009. - 532 с.

10. Макаренко Д.С. Геологічній службі України - 80 // Минерал. журн. - 1998. - 20, № 1. - С. 3-7.

11. Макаренко Д.С. Керманичі Інституту геологічних наук // Геологія в ХХІ столітті. - К. : Тов. "Знання" України, 2001. - С. $16-26$.

12. Молявко Г.И., Франчук В.П. Геологи, географы. Биограф. справ. - К. : Наук. думка, 1985. - 351 с.

13. Нариси з історії геологічних досліджень у Київському університеті / За ред. В.Г. Молявка, О.В. Зінченка. - К. : Рада, 1999. - 326 с.

14. Новик Е.О., Пермяков В.В., Коваленко Е.Е. История геологических исследований Донецкого каменноугольного бассейна (1700-1917). - Киев : Изд-во АН УССР, 1960. - 531 с.

15. Онопрієнко В.І. Володимир Іванович Лучицький. - К. : Наук. думка, 1991. - 191 с.

16. Оноприенко В.И., Оноприенко М.В. Чирвинские. - М. : Наука, 2008. - 303 с.

17. Павлишин В.И., Платонов А.Н., Таращан А.Н. Основные закономерности минералообразования на ранних этапах развития земной коры // Минерал. журн. - 1998. - 20, № 1. - С. 72-83.

18. Різниченко Володимир Васильович (18.X.1870-1.IV.1932) // Відділ. наук про Землю Нац. академії наук України. - К., 2003. - С. 68-69.

Надійшла 21.12.2017

\section{REFERENCES}

1. Bilonizhka, P., Matkovskyy, O., Pavlun, M. and Slyvko, Ye. (2010), Heolohichnyy fakultet Lvivskoho natsionalnoho universytetu imeni Ivana Franka, Vydannya druhe, VTS Lviv. nats. Univ., Lviv, UA, 520 p.

2. Pavlyshyn, V.I. (ed.) (2011), Heolohiya v Kyivskomu universyteti, VPTS Kyiv Univ., Kyiv, UA, 479 p.

3. Hoshovskyy, S.V. and Hurskyy, D.S. (1998), Mineralni resursy Ukrayiny, No. 1, Kyiv, UA, pp. 3-5.

4. Hurskyy, D.S. (2008), Kontseptualni zasady derzhavnoyi mineralno-syrovynnoyi polityky shchodo vykorystannya stratehichno vazhlyvykh dlya ekonomiky krayiny korysnykh kopalyn, ZUKTS press, Lviv, UA, 192 p.

5. (2006), Derzhavna heolohichna sluzhba, DHS Ukrayiny press, Kyiv, UA, 19 p.

6. (1993), Istoriya Akademii nauk Ukrayiny. 1918-1923. Dokumenty i materialy, Nauk. dumka, Kyiv, UA, 563 p.

7. Melnyk, Yu.P. (ed.) (1991), Istoriya mineralohicheskikh issledovaniy na Ukraine, Sb. nauch. tr., Nauk. dumka, Kyiv, UA, $160 \mathrm{p}$.

8. Lazarenko, E.K. (1948), Mineral. sb., No. 2, pp. 5-24.

9. Larchenkov, E.P., Kravchuk, O.P. and Kravchuk, A.O. (2009), Heolohiya v Odesskom universitete, Feniks press, Odessa, $\mathrm{UA}, 532 \mathrm{p}$

10. Makarenko, D.Ye. (1998), Mineral. Journ. (Ukraine), Vol. 20, No. 1, Kyiv, UA, pp. 3-7.

11. Makarenko, D.Ye. (2001), Heolohiya v XXI stolitti, Tov. Znannya Ukrayiny, Kyiv, UA, pp. 16-26.

12. Molyavko, H.I. and Franchuk, V.P. (1985), Heolohy, heohrafy. Byohraficheskyi spravochnik, Nauk. dumka, Kyiv, UA, $351 \mathrm{p}$.

13. Molyavko, V.H. and Zinchenko, O.V. (eds) (1999), Narysy z istoriyi heolohichnykh doslidzhen u Kyivskomu Universyteti, Rada press, Kyiv, UA, 326 p.

14. Novik, E.O., Permyakov, V.V. and Kovalenko, E.E. (1960), Istoriya heolohicheskikh issledovaniy Donetskoho kamennouholnoho basseyna (1700-1917), Izd-vo AN UkrSSR, Kyiv, UA, 531 p.

15. Onopriyenko, V.I. (1991), Volodymyr Ivanovych Luchytsky, Nauk. dumka, Kyiv, UA, 191 p.

16. Onopriyenko, V.I. and Onopriyenko, M.V. (2008), Chirvinskie, Nauka, Moscow, RU, 303 p.

17. Pavlyshyn, V.I., Platonov, A.N. and Tarashchan, A.N. (1998), Mineral. Journ. (Ukraine), Vol. 20, No. 1, Kyiv, UA, pp. 72-83.

18. (2003), Riznychenko Volodymyr Vasylyovych (18.X.1870-1.IV.1932), Viddilennya nauk pro Zemlyu Nats. Akad. Nauk Ukrayiny, Kyiv, UA, pp. 68-69.

Received 21.12.2017 


\section{В.И. Павлишин}

Институт геохимии, минералогии и рудообразования

им. Н.П. Семененко НАН Украины

03142, г. Киев, Украина, пр-т Акад. Палладина, 34

E-mail: V.I.Pavlyshyn@gmail.com

\section{УКРАИНСКИЙ ГЕОЛОГИЧЕСКИЙ КОМИТЕТ И ЕГО КЛЮЧЕВЫЕ ФИГУРЫ}

(к 100-летию Геологической службы Украины)

Изложена история зарождения, становления и последующего развития деятельности геологической службы Украины - Украинского геологического комитета, начиная с 1917 г. Рассмотрен весомый вклад украинских ученых - В.И. Лучицкого, Б.Л. Личкова, В.В. Ризниченко и В.Н. Чирвинского - в развитие науки, прикладной геологии, Украинского геологического комитета.

Ключевые слова: Украинский геологический комитет, Геологическая служба Украины, В.И. Лучицкий, Б.Л. Личков, В.В. Ризниченко, В.Н. Чирвинский.

\section{V.I. Pavlyshyn}

M.P. Semenenko Institute of Geochemistry, Mineralogy

and Ore Formation of the NAS of Ukraine

34, Acad. Palladin Ave., Kyiv, Ukraine, 03142

E-mail: V.I.Pavlyshyn@gmail.com

\section{THE UKRAINIAN GEOLOGICAL COMMITTEE AND ITS KEY PERSONS}

(on the $100^{\text {th }}$ anniversary of the Geological service of Ukraine)

The history of the origin, formation and subsequent development of the Geological service of Ukraine - Ukrainian Geological Committee (since 1917) is stated in the article. This article also discusses the significant contribution of Ukrainian scientists (V.I. Luchytsky, B.L. Lichkov, V.V. Riznychenko, V.M. Chyrvinsky) to the development of science, applied geology and Ukrainian Geological Committee.

Keywords: the Ukrainian Geological Committee, Geological service of Ukraine, V.I. Luchytsky, B.L. Lichkov, V.V. Risnychenko, V.M. Chyrvinsky. 